\title{
The First Act of Liberation Is to Destroy One's Cage / Michael S. Harper
}

For Black poets, in particular, the first act of liberation is to destroy one's cage; one acquires the techniques of expression, chooses one's form, has the will, makes the choice: to become an image-maker. The true poet writes out of experience transformed by technique into liberation: a transformational act, in deed. The poet's function is to force the reader/listener to change one's life, to acquire those missing parts needed to make one's survival-kit-of-escape function, to make oneself whole. Some helpful tools of technical assistance include: a sense of heroic tradition; conjure knowledge; struggle as a modal perception of living; a sense of optimism; a belief in testimony and the testamental process, for man is spiritual, an art form, to be beautified, to be educated in the manifest (seen) and the potential (unseen) aspects of his being; a rigor of improvisation that can transform one's sense of reality; the ability to focus with intent (conjure) for the magical aspects image-making; an insistence on revelation as an antidote to pathology, the healing song of transcendence through ritual, from a moral perspective, from a sense of cosmology, a sense of oneness; a knowledge of cages, many velvet-carpeted, some with magnificent views, but no vision: to look is not necessarily to see/to see is to have vision/"straight, no chaser" said the musician, says the image-maker.

\section{Free Fantasia: Tiger Flowers / Robert Hayden}

\author{
(for Michael) \\ The sporting people \\ along St. Antoine- \\ that scufflers' \\ paradise of ironies- \\ bet salty money \\ on his righteous \\ hook and jab.
}

